\title{
The Lifting of Corporate Veil Doctrine in Hong Kong: An Empirical, Comparative and Development Perspective
}

\author{
Thomas K. Cheng*
}

\begin{abstract}
This paper provides an empirical, comparative, and development perspective on the corporate veil doctrine. It contains a comprehensive survey of the corporate veil cases in Hong Kong. The survey results are then compared with comparable surveys of the US cases to highlight relevant characteristics in the Hong Kong courts' approach to the doctrine. The paper also analyses the doctrine and the limited liability principle in a development perspective to suggest that the Hong Kong courts should apply the doctrine more assertively to address externalization of corporate business costs, which is the inevitable consequence of limited liability.
\end{abstract}

Keywords: company law, lifting of corporate veil, limited liability, Hong Kong, comparative

\section{Introduction}

The lifting of corporate veil doctrine remains one of the most difficult areas of Hong Kong company law. There is a dearth of overarching guiding principles for a body of largely incoherent case law. ${ }^{1}$ On the one hand, some of the leading cases, such as China Ocean Shipping v Mitrans Shipping ${ }^{2}$ and Bakri Bunker Trading $\mathrm{v}$ The Neptune, ${ }^{3}$ suggest that Hong Kong courts share the reservations of the English courts towards the doctrine. On the other hand, the courts readily applied the doctrine to achieve justice in a number of cases. In addition, the Hong Kong courts have shown a conflicting attitude regarding the

* BA (Yale), JD (Harvard), BCL (Oxon); Attorney \& Counsellor, New York State; Assistant Professor, Faculty of Law, the University of Hong Kong; e-mail: thomas k_cheng@yahoo.com. The author wishes to acknowledge the able research assistance of Alex Lee and Ginny Ng in compiling the survey of Hong Kong corporate veil cases. This paper would not have been possible without them.

1 One Hong Kong commentator noted that ' $[i] t$ is, however, difficult to state precisely when the courts will do so in a particular case and there is no precise test or criteria upon which the courts may rely': P. Kwan, Hong Kong Corporate Law, 1st edn (Lexis-Nexis: Hong Kong, 2006) 88.

2 [1995] 3 HKC 123, HKCA.

3 [1986] HKLR 345, HKC. 
proper basis for veil lifting, in particular on the role of justice. In Good Profit Development v Leung Hoi, the Hong Kong High Court declared justice a sufficient basis for invoking the doctrine. ${ }^{4}$ This contrasts with the sentiment expressed in Nazareth V-P's judgment in China Ocean, in which he cited Gower's Principles of Modern Company Law and Adams v Cape Industries for the proposition that justice alone does not justify the imposition of shareholder liability. ${ }^{5}$

Despite this apparent lack of consensus, there are signs that the Hong Kong judiciary has become more receptive of the doctrine in recent years. The courts have sided with the claimant in the five most recent corporate veil cases dating back to 2004. Lee Sow Keng v Kelly McKenzie, ${ }^{6}$ a Hong Kong Court of Appeal case decided in 2004, was notable for its boldness in ignoring the separate legal personalities of the two companies in the case. This decision was all the more remarkable because its facts and outcome are very similar to the English case of Creasey v Breachwood Motors, ${ }^{7}$ which was subsequently overruled in Ord \& Anor v Belhaven Pubs. ${ }^{8}$ The Hong Kong court reached a different outcome in the face of practically identical facts as those in Creasey. The divergent outcomes of these two cases signal willingness on the part of the Hong Kong judges to deviate from the prevailing English approach and use the veil lifting doctrine to achieve justice.

A comprehensive understanding of the existing cases is essential to any meaningful discussion of the corporate veil doctrine. Current perceptions of the doctrine are largely informed by a number of leading judgments. While such generalizations are useful, they fail to provide a complete picture. The leading cases may not represent the general judicial attitude towards the doctrine. Moreover, the factsensitive nature of corporate veil cases means that a minor change of facts may alter the outcome of the case. In order to obtain a more complete understanding of the doctrine, an extensive empirical study of the existing cases will be conducted in this paper. As far as the author is aware, no such study has ever been done of the Hong Kong corporate veil cases. One of the goals of this paper is to fill this gap in the academic literature. The value of such an empirical study was confirmed by Professor Robert Thompson's surveys of the US corporate veil cases, which challenged some long-held beliefs about the corporate veil doctrine in the US. ${ }^{9}$ Similar to Thompson's surveys, the survey in this paper will investigate whether the claimant's success

4 [1992] 2 HKC 539, HKHC.

5 [1995] 3 HKC 123, HKCA.

6 [2004] 3 HKLRD 517, HKCA.

7 [1992] BCC 638, QBD.

8 [1998] BCC 607, CA.

9 R. Thompson, 'Piercing the Corporate Veil: An Empirical Study' (1991) 76 Cornell Law Review 1036 (hereinafter Thompson I); R. Thompson, 'Piercing the Veil Within Corporate Groups: Corporate Shareholders as Mere Investors' (1999) 12

Connecticut Journal of International Law 379 (hereinafter Thompson II). 
rate varies in accordance with factors such as the nature of the underlying claims at issue, the number and identity of shareholders in the company, the time when the case was decided, etc. It will also verify some common perceptions of the doctrine.

Aside from this empirical study, the application of the corporate veil doctrine in Hong Kong can be further illuminated by comparative analysis. The most obvious jurisdiction with which to compare would be the UK, given the close lineage of these two jurisdictions. However, it is precisely because of this lineage that a comparison with English cases may not produce useful insights. The Hong Kong courts have borrowed English precedents extensively in the past. Their approach to the doctrine has been largely in line with that of the English courts until Lee Sow Keng. ${ }^{10}$ Meanwhile, with the assistance of Thompson's surveys, a systematic comparison can be made with the American case law. This comparison will be particularly illuminating given that the American courts tend to focus on different factors when applying the doctrine. Instead of concepts commonly found in the English cases such as agency, trusteeship, and the single economic unit theory, the American courts emphasize factors such as capitalization of the company, separation of the assets of the company and its members, and observance of corporate formalities. ${ }^{11}$ This comparative study will hopefully yield useful insights into the Hong Kong courts' approach to the doctrine.

After the empirical study and comparative analysis, this paper will proceed to consider the proper role for the doctrine in Hong Kong company law. This requires an appreciation of the practical social impact of the corporate veil doctrine and the principle of limited liability. Strict adherence to that principle means that companies will escape their liabilities and leave their creditors unpaid once their assets are exhausted. This results in the externalization of business costs to the counterparties of the company, which is obviously undesirable. To put it differently, these counterparties are made to provide an implicit subsidy to the company's business activities. This paper argues that while implicit subsidies to businesses may be justified when an economy is industrializing and pursuing rapid economic growth, they are highly questionable for advanced economies such as Hong Kong's. Once an economy has attained a sufficiently high level of development, there are no persuasive justifications for businesses not to bear the full costs of their activities. The corporate veil doctrine

10 In fact, during colonial times, English cases were binding on the Hong Kong courts. After the return of sovereignty to China in 1997, English cases remain highly persuasive. Hong Kong judges still cite English company law cases extensively.

11 See Thompson I, above n. 7 at 1063-8; R. Hamilton, "The Corporate Entity' (1971) 49 Texas Law Review 979 at 982-94; C. Krendl and J. Krendl, 'Piercing the Corporate Veil: Focusing the Inquiry' (1978) 55 Denver Law Journal 1 at 15-17; D. Barber, 'Piercing the Corporate Veil' (1981) 17 Willamette Law Review 371 at 374-5. 
needs to be applied more liberally to mitigate these undesirable effects. A development perspective of the doctrine advocates an expanded role for it in Hong Kong.

This paper contains three further sections. Section II summarizes the results of the empirical study of Hong Kong corporate veil cases conducted by the author. The survey begins with a pool of 119 cases in which the corporate veil doctrine is mentioned or in some way implicated. These cases are analysed along various dimensions and trends in the case law will be deduced. Results from the analysis are then compared with those from Thompson's surveys. Where appropriate, there will be a more detailed discussion and comparison of the Hong Kong and the American cases. Section III adopts a developmental perspective on the corporate veil doctrine and limited liability. It explains how limited liability results in externalization of business costs and compels members of society to confer implicit subsidies on corporate activities. It argues that while strict adherence to limited liability may have served a useful purpose during the rapid development of Hong Kong's economy between the 1950s and the 1980s, such implicit subsidies are no longer necessary or justified. Section IV concludes the paper.

\section{An Empirical Study of Corporate Veil Cases in Hong Kong}

In light of the diverse factual circumstances in corporate veil cases and the lack of overarching guiding principles under the doctrine, the most systematic way to study these cases is through a general survey. Moreover, North American commentators have made some theoretical assertions about the corporate veil doctrine, including: first, in light of a tort victim's lack of prior opportunity to negotiate with the tortfeasor for compensation, courts should be more ready to pierce the veil in tort as opposed to contract cases; secondly, it is less of an affront to the limited liability principle to pierce the veil against a corporate shareholder because the ultimate individual shareholders of the corporate shareholder still enjoy limited liability protection; thirdly, the greater is the number of shareholders, the lower is the success rate for the plaintiff; and fourthly, undercapitalization of the corporation is one of the most important considerations in veil piercing cases. ${ }^{12}$ It was not possible to verify these assertions until Thompson's surveys, which contradicted a number of them. For example, Thompson showed that the American courts are in fact less likely to pierce the veil in tort cases than in contract cases. ${ }^{13}$ They are also more likely to pierce the veil against an individual shareholder as 
opposed to a corporate shareholder. ${ }^{14}$ The goal of this survey of the Hong Kong corporate veil cases is to decipher trends in them and to verify whether these theoretical assertions hold true for them.

The author conducted a comprehensive search for corporate veil cases in Hong Kong covering four databases, including Westlaw, Lexis-Nexis, the Hong Kong Legal Information Institute website, and the Hong Kong Judiciary website. Every case in these databases which mentions the phrase 'corporate veil' was included in the initial pool of 119 cases. Of these 119 cases, the corporate veil doctrine was tangentially at issue in 78 of them, of which the integrity of the separate corporate personality was at stake in 41 of them. These 41 cases can be further divided into two categories. The first category consists of cases in which separate corporate personality was at stake, but setting it aside would not have resulted in the imposition of shareholder liability. One example of such cases is the famous $D H N$ case decided by the English Court of Appeal. ${ }^{15}$ In that case, the parent company asked the court to treat three members of a corporate group as one entity for the purpose of assessing compensation for a government compulsory purchase. No liability was at stake. This type of corporate veil cases has been labelled as identification' ${ }^{\prime 16}$ cases or 'looking behind the veil' ${ }^{17}$ cases. The corporate veil is set aside to identify the company with its members. There are 14 of them in the survey.

The second category consists of cases in which shareholder liability was at issue. These are genuine corporate veil cases in the sense that the limited liability principle is overridden. Notable examples of such cases include Adams v Cape Industries and Creasey v Breachwood Motors. ${ }^{18}$ There are 27 of them in the survey. These 27 cases are dwarfed by the over 3,800 corporate veil cases Thompson managed to locate. ${ }^{19}$ While Hong Kong is obviously a much smaller jurisdiction than the 50 states of the USA plus its federal court system, Hong Kong is a major financial centre where entrepreneurship is vibrant. As of November 2009, there were 766,382 local companies listed on the Companies Register in Hong Kong. ${ }^{20}$ This means that there is more than one company per ten persons. In fact, the number of registered local companies increased by close to 40 per cent between 2004 and $2009 .^{21}$ Given the prevalence of companies, one would expect a much

14 Ibid.

15 DHN Food Distributors Ltd v Tower Hamlets London Borough Council [1976] 1 WLR 852, CA.

$16 \mathrm{~K}$. van de Kerckhove, Piercing the Corporate Veil, 1st edn (Kluwer Law International: Alphen aan den Rijn, 2007) 13-14.

17 See S. Ottolenghi, 'From Peeping Behind the Corporate Veil to Ignoring it Completely' (1990) 53(3) MLR 338.

18 [1990] Ch 433, CA; [1992] BCC 638, QBD.

19 See Thompson II, above n. 7 at 385 .

20 Companies Registry, Statistics-Number of Local Companies on Register in 2009, available at: http://Www.cr.gov.hk/en/statistics/statistics_01.htm. 21 Ibid. 
higher number of corporate veil cases. A number as low as 27 suggests that, for whatever reason, the corporate veil doctrine is rarely invoked in Hong Kong. One possible explanation may be that claimants are discouraged from challenging limited liability due to a perceived low probability of success. It will be interesting to see if this perception is substantiated by the cases. Before proceeding to analyse the results, one cautionary note is in order. The small sample size of this survey means that whatever observations and inferences drawn from it must be interpreted with care. As is true of any kind of statistical study, reliability is diminished as the sample size becomes smaller. With the small sample size of this survey, conclusions can only be confidently drawn if the variations in trends are substantial.

On a theoretical level, one may expect the US courts to be more ready than the Hong Kong courts to lift the veil in light of the concessionaire approach to incorporation under US law. Under US corporation law, the benefits of incorporation are a privilege granted by the sovereign. There is thus a stronger theoretical basis for the withdrawal of such benefits when the corporate form has been abused. What the legislature grants it can also revoke. The United States District Court for the Southern District of New York articulated this view in Mull $\mathrm{v}$ Colt, declaring that '[c]ertainly a concomitant of the favor of the sovereign in permitting a corporate form of doing business is that the conduct of the entity be compatible with the public interest. The corporate fiction is but a matter of commercial convenience; the concept is not to be extended beyond reason and policy.'22 This is to be contrasted with the contractual approach to incorporation under Anglo-Hong Kong law, under which the constitutional documents of a company are deemed to be a contract between the company and its members and the members inter se. ${ }^{23}$ Incorporation is not a privilege granted by the sovereign, but a process initiated by and premised upon the will of private parties. Therefore, one may argue that veil lifting is more susceptible to the charge of interference with private contractual right under Anglo-Hong Kong law than under US law, and hence more difficult for the Hong Kong courts to defend and countenance.

The first observation about the survey results is that, contrary to the general perception, the Hong Kong courts have been quite willing to lift the veil. Among the 41 cases in which separate corporate personality was at stake, the courts lifted the veil in 18 of them. The claimant success rate was 43.9 per cent, which is in fact higher than that among the US cases. Thompson found that the plaintiff succeeded in roughly 40 per cent of the US corporate veil cases. ${ }^{24}$ This

2231 FRD 154 at 166 (SDNY 1962)

23 P. Davies, Gower and Davies: Principles of Modern Company Law, 8th edn (Sweet \& Maxwell: London, 2008) 65-6.

24 See Thompson I, above n. 7 at 1048. 
result is surprising given the Hong Kong courts' generally conservative reputation. In fact, if one focuses on the second category of cases, the genuine corporate veil cases, the claimant success rate was 48 per cent. Of the 27 cases, the veil was lifted in 13 of them. This result further belies the Hong Kong judiciary's reputation of cautiousness towards veil lifting. Given this high rate of success, the dearth of corporate veil cases in Hong Kong is even more surprising. It is possible that potential claimants' perception of their likelihood of success is tainted by a few prominent cases in which the court refused to lift the veil.

\section{i. The Nature of the Underlying Claims at Issue}

The subsequent analysis will focus on the 27 genuine corporate veil cases. Among them, 14 involved contractual claims, none involved tort claims, five were criminal cases, and eight arose in a statutory context. It is surprising that no corporate veil claim has ever been raised in a tort case in Hong Kong. It has been suggested by North American commentators that the courts should be more ready to lift the veil in tort cases. As mentioned earlier, this was contradicted by the results from Thompson's surveys. He found that US courts pierced the veil in 42 per cent of the contract cases and 31 per cent of the tort cases. ${ }^{25}$ He further found that US courts pierced the veil in 67 per cent of the criminal cases and 41 per cent of those cases involving statutory claims. ${ }^{26}$ In light of the absence of corporate veil cases premised on tort claims in Hong Kong, it is impossible to verify whether the courts are more ready to lift the veil in tort cases. The Hong Kong courts lifted the veil in five of the 14 contract cases, or 35.7 per cent of them. Consistent with the trends in the US, the Hong Kong courts have more aggressively applied the doctrine in criminal cases. Of the five corporate veil cases arising in the criminal context, the courts lifted the veil in four, or 80 per cent, of them. Lastly, the Hong Kong courts have lifted the veil in a higher percentage of statutory cases than have the US courts. Of the eight cases predicated on statutory claims, the Hong Kong courts lifted the veil in five, or 62.5 per cent, of them. ${ }^{27}$ Therefore, in Hong Kong, claimant success rates vary according to the nature of the underlying claims. Criminal cases have seen the highest success rate, followed by statutory cases, and then by contractual cases. This is roughly consistent with the trend in the US.

$25 \mathrm{Ibid}$. at 1058, 1069. The difference in success rate is smaller once one takes out the misrepresentation cases. The American courts pierced the veil in 34 per cent of the contract cases not involving misrepresentation and 27 per cent of the tort cases not involving misrepresentation.

26 See Thompson I, above n. 7 at 1058.

27 Adding all the cases in which the veil was lifted in the three categories, there are in fact 14 of them, which is one more than the 13 successful corporate veil cases mentioned above. The reason is that one of them consisted of both contractual and statutory claims. 


\section{(a) Criminal Cases}

It is worth pondering the variations in success rate among different case types. As far as criminal cases are concerned, the greater judicial willingness to lift the veil could be attributed to the fact that the courts do not want to allow defendants to escape criminal sanctions through the use of the corporate form. HKSAR v Leung Yat Ming aptly illustrates this. ${ }^{28}$ In that case, the defendants attempted to circumvent university regulations on the use of housing allowance by incorporating a company. Those regulations prohibited university employees from using their housing allowance to purchase property. It could only be used for rental payment. The defendants attempted to bypass this prohibition by incorporating a company to purchase the property, which was subsequently leased to them by the company. The court did not hesitate to impute ownership of the property to the two defendants, which rendered them in violation of a criminal statute. In the court's view, the corporate form cannot be used in such a transparent manner to circumvent the university regulations.

At first glance, the view expressed by the Leung Yat Ming court seems convincing. The court's view was that the policy objective of a criminal statute should not be frustrated by the use of the corporate form. By choosing to criminalize certain conduct, the legislature has indicated the reprehensibility of that conduct and the importance of deterring it. The legislature's judgment should be honoured to the greatest extent possible, including by overriding the separate personality of companies. However, the contrary view is that given the moral stigma of a criminal conviction and the high burden of proof required of the prosecution in establishing a criminal offence, the corporate veil should not be lightly lifted. ${ }^{29}$ The defendants in Leung Yat Ming had not been put on adequate notice of the criminal consequences of their action. Given the Hong Kong courts' repeated proclamations that corporate property does not belong to the members of a company, ${ }^{30}$ it was legitimate for the defendants to assume that the separate personality of their company would have been respected. The university regulations only required the defendants to declare that neither they nor any of their relatives owned the property. ${ }^{31}$ The practice of using a company to hold properties was common enough in Hong Kong that the university authority should have been aware of the possibility. ${ }^{32}$ If the university authority had intended to prohibit the use of the corporate form to circumvent the regulations, it could

28 [1999] 2 HKLRD 402, HKCA.

29 In that case, the defendants were actually charged with violating university regulations on the use of housing allowance, which constituted a criminal offence under the Prevention of Bribery Ordinance, which prohibits the deception of its principal by an agent.

30 Good Profit Development Ltd v Leung Hoi [1992] 2 HKC 539, HKHC; Terrain Ltd and Ors v Oriental Peer Co. Ltd [1988] 1 HKLR 246, HKCA.

31 [1999] 2 HKLRD 402 at 405.

32 This has been remarked upon by the Good Profit court. 
have expressly stated so. The defendants should not have been made to suffer criminal consequences because of the university authority's drafting oversight. There is in fact a close parallel between Leung Yat Ming and the English case Tunstall v Steigman. ${ }^{33}$ Tunstall was not a criminal case; it involved a statute governing the repossession rights of a landlord. In that case, the court held that the landlord could not repossess her property because the business that was going to occupy the premises was owned by the landlord's company, not the landlord herself. The court adopted a literal interpretation of the statute and insisted on the distinct legal personalities of the landlord and her company. The implicit belief of the court was that if Parliament deemed this interpretation to be contrary to its intentions, Parliament could amend the statute, which it did. The argument for a strict literal interpretation is perhaps even stronger for a criminal statute.

This is the view expressed by Cardozo $\mathrm{J}$, a prominent jurist who went on to become a US Supreme Court justice, in Berkey v Third Avenue Railway Corporation, a leading American corporate veil case. ${ }^{34}$ In that case, the plaintiff attempted to recover from the parent company for the personal injury she had sustained due to the negligence of the employees of the subsidiary company. She argued that the veil of the subsidiary should be pierced and the two companies should be treated as one for the purpose of her compensation. However, piercing the veil would have also resulted in a violation of a penal statute. Cardozo $\mathrm{J}$ asserted that no such inference is to be drawn from acts so uncertain [ownership of shares and overlapping personnel] in their suggestions where the inference is also one of the commission of a crime. ... an intention to operate a route in violation of a penal statute is not to be inferred from acts which reasonably interpreted are as compatible with innocence as with guilt' ${ }^{35} \mathrm{He}$ refused to pierce the veil of the subsidiary to let the victim seek compensation from the corporate parent. Cardozo J similarly believed that it should be more, not less, difficult to pierce the veil in a criminal case. Even the Hong Kong courts have not always shared the aggressive stance of the Leung Yat Ming court on veil lifting in criminal cases. In HKSAR v Sin Law Yuk Lin, the Court of Appeal, while affirming the lower court's decision to lift the veil to establish a criminal violation, did not treat the corporate veil issue any differently from its treatment in a civil case. In fact, the Court of Appeal affirmed the application of the legal standard for veil lifting laid down by Lord Keith of Kinkel in Woolfson v Strathclyde Regional Council, ${ }^{36}$ which was a civil case. The different sentiments expressed by Cardozo J and the Sin Law Yuk Lin court notwithstanding, the fact remains that both the American and 
the Hong Kong courts are considerably more willing to lift the veil in a criminal case.

\section{(b) Contract and Tort Cases}

The Hong Kong courts' relatively cautious stance in contract cases as compared to the other types of cases can be explained by the belief that in a contract case, the parties had the opportunity to negotiate for whatever terms and protections they desired. If a party neglected to negotiate for a particular protection ex ante, it should not be allowed to alter the contractual bargain ex post by way of veil lifting. Veil lifting, after all, amounts to an ex post revision of the contractual bargain. Bokhary JA encapsulated this view when he proclaimed in China Ocean that it was Mitrans Panama who entered into the charterparties and who assumed liabilities or obligations to the plaintiff thereunder. The plaintiff chose to deal with Mitrans Panama without insisting on a guarantee. ${ }^{37}$ In that case, the plaintiff was trying to recover from Mitrans Shipping, a company which shared many senior employees with Mitrans Panama. The plaintiff had entered into charterparties with Mitrans Panama without a guarantee from Mitrans Shipping. Bokhary JA was clearly of the view that if the plaintiff had wanted Mitrans Shipping to be liable for the charterparties, it should have demanded a guarantee in the initial contract negotiation. The Mitrans companies probably would have asked for something in return, perhaps in the form of higher fees for the charterparties. This view is largely consistent with that of the English courts and the arguments put forward by the law and economics scholars from North America, such as Professors Easterbrook and Fischel of the University of Chicago and Professors Halpern, Trebilcock and Turnbull of the University of Toronto. ${ }^{38}$

This author has not found any Hong Kong tort cases in which the corporate veil doctrine was invoked. Therefore, there are no bases upon which to predict how Hong Kong courts will decide corporate veil claims in a tort case. Still, some non-tort precedents have provided useful clues. In China Ocean, Bokhary JA drew a distinction between evasion and avoidance of legal obligations. He proclaimed that:

Using a corporate structure to evade legal obligations is objectionable. The courts' power to lift the corporate veil may be exercised to overcome such evasion so as to preserve legal obligations. But using a corporate structure to avoid the incurring of any legal obligation in the first place is not objectionable. And the courts' power to lift the corporate

37 China Ocean Shipping Co. v Mitrans Shipping Co. Ltd [1995] 3 HKC 123, HKCA, at para. 16.

38 P. Halpern, M. Trebilcock and S. Turnbull, 'An Economic Analysis of Limited Liability in Corporation Law' (1980) 30 University of Toronto Law Journal 117; F. Easterbrook and D. Fischel, 'Limited Liability and the Corporation' (1985) 52 University of Chicago Law Review 89. 
veil does not exist for the purpose of reversing such avoidance so as to create legal obligations. ${ }^{39}$

This evasion-avoidance dichotomy has been endorsed in subsequent cases. ${ }^{40}$ Evasion of existing legal obligations justifies veil lifting, whereas using the corporate form to avoid the incurrence of legal obligations in the first place is legitimate. In other words, the key to deciding the validity of a corporate veil claim is the relative timing between the incurrence of legal obligations and the incorporation. The ease of application of this rule depends on the type of liability at issue. The time of creation of a contractual obligation is probably easily ascertainable. For torts that take place at a discrete point in time, determination of the time of incurrence of liability will be similarly straightforward. In contrast, it is not easy to determine when a liability is incurred when the tort at issue takes place over time, such as prolonged exposure to a harmful substance or other bodily harm. For example, it will be difficult to determine when a liability is incurred if the tort involves daily exposure to deafening noise in a workplace that results in an impairment of hearing. The impairment takes place gradually over time and is the result of repeated exposure to the noise. There is no single point in time at which the liability can be said to arise.

Apart from the difficulty in application to certain tort claims, this evasion-avoidance dichotomy will pose serious obstacles to a corporate veil claim in tort cases. In most cases, the company will be incorporated first, begins operation, and then a tort arises in its operation. Under these circumstances, the legal obligation is incurred after incorporation, which means that the veil will not be lifted. It is by similar reasoning that the English Court of Appeal rejected the corporate veil claims in Adams v Cape Industries. ${ }^{41}$ The Court of Appeal was of the view that there is nothing objectionable about a corporate group sequestering its most hazardous operations within one subsidiary in order to limit the liability exposure of the group. The one scenario in which the veil may be lifted is when the members of a company that is subject to tort liability close down the first company and incorporate a new one to continue the existing operations. In that case, one may argue that the tort obligation is incurred before the incorporation of the second company. However, Adams has shown what the members can do in order to insulate the second company from liability. In that case, the second company, which was created after the tort liabilities had arisen, was managed by the corporate parent through a complex chain of ownership involving a dummy company in Liechtenstein.

39 [1995] 3 HKC 123, HKCA, at para. 17.

40 Liu Hon Ying v Hua Xin Enterprise (Hong Kong) Ltd [2003] 3 HKLRD 347, HKCFI.

41 [1990] Ch 433, CA. 
That has effectively prevented the liability of the first company, the original tortfeasor, from being imputed to the second company.

In sum, in light of the evasion-avoidance dichotomy laid down in China Ocean, the Hong Kong courts probably will be more ready to lift the veil in contract than in tort cases. For corporate veil claims to have a greater chance of success in tort cases, the China Ocean dichotomy will need to be reformulated or perhaps confined to contract cases. As China Ocean itself was a contract case, it is plausible to limit the application of its rule to those cases.

\section{(c) Statutory Cases}

For corporate veil cases involving statutory claims, the success rate between that for criminal cases and contractual cases is consistent with the results of Thompson's surveys, and to some extent also with the attitude of the English courts. It may be recalled that Thompson's surveys showed that American courts are most willing to pierce the veil in criminal cases, followed by statutory cases, and then by contract cases. Thompson detected different degrees of willingness to pierce the veil on the part of the American courts depending on the statutes at issue. ${ }^{42}$ At least according to his first survey, the American courts were much more willing to pierce the veil in cases involving employee pensions, environmental law, and patent law than workers' compensation or tax statutes. ${ }^{43}$ As for the English corporate veil cases, Professor Davies declared in his book that the 'doctrine of lifting the veil plays a small role in British company law, once one moves outside the area of particular contracts or statutes' ${ }^{44}$ A quick glance at the English corporate veil cases suggests that English courts have shown considerable readiness to lift the veil in cases involving statutory claims, including Re FG (Films), ${ }^{45}$ the DHN case, and a slew of revenue cases. Enthusiasm for the corporate veil doctrine wanes in contract cases. Notable examples of contract cases in which the separate corporate personality was upheld include Yukong Line v Rendsburg Investment Corporation, Ord \& Anor v Belhaven Pubs, and Macaura v Northern Assurance. ${ }^{46}$

There have been only ten Hong Kong corporate veil cases involving statutory claims so far. The claims have ranged from insolvency (one case) to divorce (two), from maritime (two) to garnishment (one), ${ }^{47}$

42 See Thompson I, above n. 7 at 1060-2.

43 Ibid. at 1062 , n. 135. Although in a later update of his survey, Thompson did find that the courts' willingness to pierce the veil in pensions and environmental law cases receded to the mean for all statutory cases.

44 See Davies, above n. 21 at 208-9.

45 [1953] 1 All ER 615, Ch D.

46 [1998] 1 WLR 294, QBD; [1998] BCC 607, CA; [1925] AC 619, HL.

47 The statute at issue in the case was the Transfer of Business (Protection of Creditors) Ordinance. 
and from tax (one) to real property (one). There were two cases involving other kinds of statute. ${ }^{48}$ Given the small sample size in each category, no reliable generalizations can be made about variations in judicial attitude towards different types of statutory claims. For what it is worth, the Hong Kong courts have lifted the veil in every divorce, garnishment, and tax case, and have refused to do so in every other statutory case. The variations can be explained by the courts' recognition of the disparate policy rationales behind the statutes. Take matrimonial law as an example. In $W$. v $H$. and Another, Saunders J of the Court of First Instance proclaimed that the corporate form will not be allowed to frustrate the policy behind the Matrimonial Proceedings and Property Ordinance:

In matrimonial proceedings the court will not hesitate to pierce the corporate veil, and, where property is vested in a one-man company which is the alter ego of the husband, disregard corporate ownership and, without requiring a company to be joined at [sic] a party make an order which has the same effect as the order that would be made if corporate property were vested in the husband. ${ }^{49}$

The judge proceeded to set aside the transactions that put the husband's assets out of the wife's reach. Such an assertive stance is justified given the prevalent use of trusts and corporate vehicles in Hong Kong to evade the property distribution rules in matrimonial law. Thompson noted the same tendency of the American courts to tailor the corporate veil doctrine to the policy rationale of the statute at issue. ${ }^{50}$ In this respect, the Hong Kong and the American courts are similar.

\section{ii. The Number of Shareholders}

Aside from the nature of claims at issue, another possible dimension along which to gauge variations in judicial attitude is the type of company at issue. For example, courts may exhibit different attitudes towards veil lifting in public and private companies. Their attitude may also vary depending on the number of members in the company. Thompson found that the American courts did not pierce the veil against a single public company among the over 1,600 cases in his first survey. ${ }^{51}$ Of the 27 Hong Kong corporate veil cases in this survey, only one of them, Re Wah Nam Group Ltd, involved a public company. ${ }^{52}$ The Court of First Instance refused to lift the veil in that case. It is of course difficult to draw any general conclusions from a one-case

48 These statute classifications are based on those used by Thompson in his survey. This is done to allow comparison of results from the Hong Kong cases with those from Thompson's surveys.

49 [2008] HKEC 766, HKCFI, at para. 169

50 See Thompson I, above n. 7 at 1060-2.

$51 \mathrm{Ibid}$. at 1047.

52 [2000] HKEC 875, HKCFI. 
sample group. ${ }^{53}$ It is worth noting that in rejecting the corporate veil claim in Re Wah Nam Group, the court put no emphasis on the fact that the company at issue was a public one. While one should avoid reading too much into this omission, it does leave open the possibility that the Hong Kong courts may lift the veil against a public company under appropriate circumstances.

Thompson found that the American courts' readiness to pierce the veil is inversely related to the number of shareholders in the company. His first survey showed that the American courts pierced the veil in 35 per cent of the cases involving companies with more than three shareholders. ${ }^{54}$ The percentage increases to 46 per cent as the number of shareholders drops to two or three. It further increases to close to 50 per cent for single-shareholder companies. This result is consistent with the general belief that the greater is the number of shareholders, the more likely it is that the court will treat the corporation as legitimate. ${ }^{55}$ Survey of the Hong Kong cases produced surprising results on the correlation between the number of shareholders and the claimant's success rate. Somewhat counter-intuitively, the Hong Kong courts are more willing to lift the veil against companies with a larger number of shareholders. The claimant success rate rises from 57 per cent (four out of seven cases) for single-shareholder companies to 67 per cent (six out of nine cases) for companies with two or three shareholders to 100 per cent (one out of one case) for companies with more than three shareholders. It is unclear what accounts for this trend. One possibility is that the Hong Kong courts may believe that the greater number of members means a higher likelihood of full recovery for the claimant once the veil is lifted. More shareholders mean potentially a greater pool of assets to satisfy the claimant. However, a quick review of the cases shows that this concern did not seem to have motivated the courts.

\section{iii. The Identity of the Shareholders}

Some North American commentators have argued that courts should be less willing to lift the veil against individual shareholders as opposed to corporate shareholders, because with the latter group the ultimate individual shareholders are still protected by limited liability. ${ }^{56}$ These individual shareholders are not deterred from investing in corporate ventures, the encouragement of which is one of the main purported benefits of limited liability. Some others have justified the disparate treatment of corporate and individual shareholders on the

53 In fact, the proportion of Hong Kong cases involving public companies is already higher than that for the American cases. In Thompson's first survey, only nine out of 1,600 cases involved a public company.

54 See Thompson I, above n. 7 at 1055.

55 Ibid. at 1056.

56 See Easterbrook and Fischel, above n. 35 at 111; Krendl and Krendl, above n. 9 at 43; J. Landers, 'A Unified Approach to Parent, Subsidiary, and Affiliate Questions in Bankruptcy' (1975) 42 University of Chicago Law Review 589 at 619. 
grounds that a corporate shareholder has greater incentives to engage in fraudulent inter-corporate transactions because the corporate shareholder often operates its own business and stands to gain more from such transactions. ${ }^{57}$

Contrary to the argument of these commentators, results from Thompson's surveys suggest that American courts in fact have been more ready to pierce the veil against individual shareholders. ${ }^{58} \mathrm{Re}$ sults from the survey of Hong Kong cases concur with Thompson's results. The Hong Kong courts lifted the veil in 65 per cent (11 out of 17 cases) of the corporate veil cases involving individual shareholders, and 14 per cent (one out of seven cases) of the cases featuring corporate shareholders. ${ }^{59}$ Even though the sample sizes are small, the discrepancy in the success rates is significant enough to permit a confident inference that Hong Kong courts lift the veil more readily against individual shareholders. It is not entirely clear what accounts for this discrepancy. One possibility is that corporate groups are more likely to be legitimate businesses with substantial operations than small companies owned by one or a few individuals. In one of the most famous corporate veil cases in the US, Walkovszky v Carlton, the New York Court of Appeal expressed this very sentiment. ${ }^{60}$ The same act done by a corporate parent may carry greater legitimacy than if done by an individual shareholder. ${ }^{61}$ For example, a corporate parent nominating one of its employees as a subsidiary's director will probably sound less nefarious than an individual shareholder appointing himself to the same position.

\section{iv. Reasons Given by the Courts}

Another important dimension along which to analyse variations in judicial attitude are the reasons given by the courts to lift the veil. The goal of the analysis is to determine how often the courts actually lifted the veil after they concluded that there had been, say, an evasion of existing legal obligations or an agency relationship between the members and the company. In other words, the goal is to determine the outcome predictiveness of each basis. The common bases given by the English and the Hong Kong courts include agency, trusts, fraud, evasion of existing legal obligation, group enterprise, justice, and the single economic unit theory. In order to assess the outcome predictiveness of these bases, this survey tallies the number of cases in which the courts invoked these bases to justify veil lifting. It also

57 M. Eisenberg, 'Megasubsidiaries: The Effect of Corporate Structure on Corporate Control' (1971) 84 Harvard Law Review 1577 at 1613.

58 See Thompson I, above n. 7 at 1056.

59 The Court of First Instance had lifted the veil against the corporate parent in Horace Yao Yee Cheong v Pearl Oriental Innovation, but the judge was subsequently overruled by the Court of Appeal. Horace Yao Yee Cheong $v$ Pearl Oriental Innovation Ltd [2009] HKEC 843, HKCA.

$6018 \mathrm{NY} 2 \mathrm{~d} 414,223 \mathrm{NE} 2 \mathrm{~d} 6$ at 8 (NY 1966).

61 See Thompson II, above n. 7 at 391. 
tallies the number of cases in which the court mentioned the absence of these bases when refusing to lift the veil. These two tallies should reveal the importance of these bases in a court's veil lifting decision.

A quick glance at the results of the tallies shows that unsurprisingly, the most predictive basis is the presence or absence of fraud. Fraud was invoked to justify veil lifting in six cases. ${ }^{62}$ Its absence accounted for upholding of separate corporate personality in seven cases. Similar to the English courts, the Hong Kong courts seem to use the term fraud broadly. Nikkodo v Lam Chiu Kau aptly illustrates this. ${ }^{63}$ Even though the Court of First Instance cited fraud as a basis for imposing liability on the director-controlling shareholder, the conduct at issue was two specific misrepresentations. The first misrepresentation was that the company would pay for the goods it had ordered, and the second that it would honour the cheques issued by it on the dates stated on these cheques. Ngo Tai Hong v Endenne Development Ltd is another case in which the court lifted the veil on the grounds of fraud based on misrepresentations made by members of the company. ${ }^{64}$ It is unclear whether the conduct at issue in these two cases would have amounted to common law fraud. The courts did not attempt to so establish. This is unsurprising given the exacting standard of proof of fraud required by the common law. Instead, the courts seemed to have classified the conduct at issue as fraud simply based on elements of dishonesty.

The prominence of fraud as a veil lifting basis among the Hong Kong cases parallels the role of misrepresentation in the US corporate veil jurisprudence. Thompson's surveys found that misrepresentation was one of the most predictive factors of the outcome of a corporate veil case. In cases in which misrepresentation was present, the American courts pierced the veil in 92.3 per cent of them. ${ }^{65}$ In cases in which the absence of misrepresentation was noted, the courts upheld separate corporate personality in 92.3 per cent of them. ${ }^{66}$ This comparable prominence of fraud and misrepresentation as a veil lifting basis in their respective jurisdictions should come as no surprise as these two terms often refer to similar conduct. In both jurisdictions they often encompass general dishonest conduct. ${ }^{67}$ Take Endenne Development as an example. The Hong Kong court characterized the

62 These six cases were: HKSAR v Leung Yat Ming [1999] 2 HKLRD 402, HKCA; Nikkodo v Lam Chiu Kau [2000] 1 HKLRD 204, HKCFI; HKSAR v Sin Law Yuk Lin, Agnes [2002] HKEC 622, HKCA; Lee Sow Keng Janet v Kelly McKenzie Ltd [2004] 3 HKLRD 517, HKCA; Ngo Tai Hong v Endenne Development Ltd [2005] HKEC 2120, HKCA; and HKSAR v Lim Jackson Lung Hin [2006] HKEC 1165, HKCA.

63 [2001] 1 HKLRD 204, HKCFI.

64 [2005] HKEC 2120, HKCFI.

65 See Thompson I, above n. 7 at 1063.

$66 \mathrm{Ibid}$. at 1065.

67 See Krendl and Krendl, above n. 9 at 28 (noting that misrepresentation should be understood to encompass a wider range of actions than common law frauds). 
misrepresentations made by the members of the company as fraudulent.

The second most frequently cited basis in the Hong Kong corporate veil cases is the evasion of existing legal obligations. It was mentioned in three successful cases. ${ }^{68}$ The absence of evasion was highlighted in three cases in which the corporate veil claim failed. ${ }^{69}$ This suggests that Adams, which discussed at some length the distinction between avoidance and evasion of legal obligations, has had considerable impact on the development of the Hong Kong corporate veil jurisprudence. There is no direct equivalent of evasion of existing legal obligations under the US corporate veil doctrine. The most similar concept under US law would be asset stripping, which refers to the 'diversion of corporate assets from the corporation by or to a stockholder or other person or entity to the detriment of creditors' ${ }^{70}$ In particular, it may refer to the removal of assets from a company in order to avoid an impending liability. A number of US cases, including World Broadcasting System $\mathrm{v}$ Bass $^{71}$ and Henderson $\mathrm{v}$ Rounds \& Porter Lumber, ${ }^{72}$ have held that evidence of asset stripping supports the imposition of shareholder liability. Evasion of existing legal obligations and asset stripping are functional equivalents to the extent that assets of the first company are transferred to a second company. In that case, the incurrence of legal obligation precedes the incorporation of the second company, and the veil will be lifted under Hong Kong law, just as asset stripping may result in shareholder liability under US law. If the corporate assets were only transferred to the members without the involvement of a second company, however, no existing legal obligations are evaded. Other company law doctrines will have to be called upon to sanction the shareholders.

The remaining bases for veil lifting do not seem to have featured prominently in the Hong Kong cases. The single economic unit theory and group enterprise were mentioned in two successful corporate veil cases each, while the absence of an agency relationship and a trustee relationship between the members and the company was mentioned in one and two cases respectively in which separate corporate personality was upheld. On the whole, it seems that fraud and evasion of existing legal obligations are the only two reliable bases on which to predict the outcome of a corporate veil case in Hong Kong.

68 These cases were: Centaline Property Agency Ltd v Cyberspeed Technology Co. Ltd [2007] 4 HKLRD 745. HKDC; Lee Sow Keng Janet v Kelly McKenzie Ltd [2004] 3 HKLRD 517. HKCA; and Liu Hon Ying v Hua Xin State Enterprise (Hong Kong) Ltd [2003] 3 HKLRD 347, HKCFI.

69 These three cases were: China Ocean Shipping Ltd v Mitrans Shipping Co. Ltd [1995] 3 HKC 123, HKCA; Maxgood International Ltd v Charter Victory International Ltd [2001] 3 HKLRD 547, HKCFI; and Lee Thai Lai v Wong Chung Kai [2004] 1 HKLRD D12, HKCFI.

70 See Barber, above n. 9 at 375.

71160 Tex. 261, 328 SW 2d 863 (Tex. 1959).

7299 F. Supp. 376 (WD Ark. 1951). 


\section{v. Trends Over Time}

The last dimension along which to analyse the Hong Kong corporate veil cases is temporal. Specifically, it is interesting to see whether the Hong Kong courts' attitude towards veil lifting has changed over time. A number of observations can be made. First, there has been a substantial increase in corporate veil cases after 2000. Of the 27 cases examined in this survey, 18 of them were decided in the 2000s. Five of them were decided in the 1990s and four in the 1980s. The author has not found a corporate veil case from before the 1980s. It is unclear what explains the surge in corporate veil cases in the 2000s. One hypothesis is that the number of corporate veil cases filed is correlated with the state of the general economy. As the economy deteriorates, more companies struggle and become insolvent. Creditors which are unable to recover their debts from the corporate assets attempt to recover directly from the members by invoking the corporate veil doctrine.

After decades of continuous growth, the Hong Kong economy was hit by a severe recession following the Asian Financial Crisis in 1998. The economy briefly recovered at the turn of the millennium, but took a nosedive again after the burst of the dotcom bubble in the US in 2001 and the SARS epidemic in 2003. This is reflected in a rapid rise in the number of voluntary bankruptcy petitions filed between 1998 and 2003. The number increased from 1,362 in 1998 to 5,487 in 2000 and peaked in 2002 at 26,922 filings. ${ }^{73}$ In the space of four years, the number of voluntary petitions skyrocketed by close to 1,880 per cent. The number began to drop in 2003 to 22,092 and then to 12,489 in $2004 .^{74}$ The number of compulsory winding-up petitions filed also rose dramatically over the same period. It rose from 723 in 1998 to 910 in 2000. It again peaked in 2002 at 1,292 petitions. ${ }^{75}$ Although the increase is nowhere near as dramatic as that in the number of voluntary petitions, it is still a staggering 79 per cent. Meanwhile, 11 of the 27 corporate veil cases in Hong Kong were filed between 1998 and 2003. Some of them involved companies in financial trouble, such as $R e$ Nam Wah Group, Toptrans v Delta Resources, and Re Landune International Limited. ${ }^{76}$ However, other corporate veil cases filed during this period did not feature struggling companies and seemed to be unrelated to the city's economic difficulty at the time. Therefore, the hypothesis only partially explains the surge in corporate veil cases in the 2000s.

73 Official Receiver's Office, Statistics on Compulsory Winding-up and Bankruptcy for the Period 1-1998 to 12-2008, available at: http://www.oro.gov.hk/cgi-bin/oro/stat. cgi?stat type $=$ W\&start_year $=1998 \&$ start_month=1\&end_year=2008\&end_month $=$ $12 \&$ Search $=$ Search.

74 Ibid.

75 Ibid.

76 [2000] HKEC 875, HKCFI; [2005] 1 HKLRD 635, HKCFI; [2005] 4 HKLRD 46, HKCA. Even though Re Landune International was filed in 2004, the losses that led to the company's winding up were sustained during the recession period up to 2003. 
The second observation about trends in the corporate veil cases over time is a gradual increase in success rate. The claimant's success rate rose from 25 per cent (one out of four cases) in the 1980s to 60 per cent (three out of five cases) in the 1990s. The success rate has stayed roughly the same since at 50 per cent (nine out of 18 cases) in the 2000s. Therefore, it seems that Adams has had a smaller impact on the corporate veil jurisprudence in Hong Kong than in the UK, where it is said to have reduced the corporate veil doctrine into insignificance. Adams was decided in 1990 and the Hong Kong Court of Appeal cited it extensively in China Ocean in 1995. Somewhat surprisingly, the claimant's success rate in corporate veil cases has in fact risen since Adams and China Ocean.

A review of the case law does not suggest any obvious reason for the rise in claimant success rate since the mid-1990s. One possibility is that the Hong Kong courts were only gaining familiarity with the corporate veil doctrine in the 1980s and became more emboldened to apply it in the 1990s. After all, Barki Bunker, the first case this author was able to locate in which the claimant invoked the corporate veil doctrine to impose shareholder liability, was only decided in 1985 . The court rejected the veil lifting claim in that case. The first successful corporate veil case was Commissioner of Inland Revenue v Waylee Investments, which was decided in 1988. Given the short history of the doctrine, the Hong Kong courts may have only become accustomed to it in the 1990s.

This explanation is supported by trends in the case law. The early cases in which the courts lifted the veil were relatively easy cases. Waylee Investments was a revenue case, which has traditionally seen a higher success rate even in the UK. ${ }^{77}$ The Waylee court may have felt more ready to lift the veil in light of the weight of the English authorities, which were still binding on Hong Kong courts at the time. Million-Add Development v Secretary for Transport, which was a compulsory purchase case similar to DIN, saw the Lands Tribunal lift the veil solely on the authority of DHN. Leung Yat Ming and Secretary for Justice v Lee Chau Ping ${ }^{78}$ were criminal cases, which, rightly or wrongly, have been perceived by the courts as easier cases for veil lifting. The first successful corporate veil cases in Hong Kong involving contractual claims, Nikkodo and Yue Tai Plywood \& Timber v Far East Wagner Construction, were not decided until the early 2000s. The first four contract cases, including China Ocean and Bakri Bunker, all

77 Revenue cases have included: Apthorpe v Peter Schoenhofen Brewing Co. [1899] 15 TLR 245, CA; Commissioners of Inland Revenue v Sansom [1921] 2 KB 492, CA;

Firestone Tyre and Rubber Co. Ltd v Lewellin (Inspector of Taxes) [1957] 1 WLR 464, HL; The Gramophone and Typewriter, Ltd v Stanley [1908] 2 KB 89, CA; Littlewoods Mail Order Stores Ltd v Inland Revenue Commissioners [1969] 1 WLR 1241, CA; Southern v Watson [1940] 3 All ER 439, CA; and St. Louis Breweries, Ltd v Apthorpe [1898] 15 TLR 112, QBD. English courts by and large have seemed to be more willing to lift the veil in revenue cases.

78 [2000] 1 HKLRD 49, HKCFI. 
resulted in judgments for the defendants. This seems to suggest that the success rate in the 1990s and 2000s may be the longer-term norm in Hong Kong.

\section{The Future of the Corporate Veil Doctrine in Hong Kong}

\section{i. A Theoretical Discussion of the Limited Liability Principle and the Corporate Veil Doctrine}

The short history of the corporate veil doctrine in Hong Kong means that there is still much room for evolution. While, historically, the Hong Kong courts have by and large followed the lead of the English courts when applying the doctrine, recent cases such as Lee Sow Keng suggest that the local courts may be willing to go beyond their English counterparts. It is therefore worth pondering the proper role for the doctrine in Hong Kong company law.

At this juncture, it is important to recall the precise function of the doctrine and its practical social impact. The corporate veil doctrine is an exception to the general company law principle of limited shareholder liability. ${ }^{79}$ Under this principle, liabilities incurred by the company, be they of contractual, tortious or other nature, are the company's sole responsibilities. Absent exceptional circumstances, the shareholders will not be held liable for them. If corporate assets are insufficient to cover certain liability, the shortfall will have to be borne by the counterparty. This counterparty may be a creditor of various kinds. ${ }^{80}$ He may be a financial creditor who has signed a loan agreement with the company. He may be a trade creditor who has agreed to supply goods to the company with or without a formal agreement. He may be an employee who has signed an employment contract with the company to offer his labour service to it. Furthermore, he may be a tort victim who has sustained an injury from the company's business activities. For example, he may have been injured by a company vehicle while the vehicle is on company business. Regardless of the type of creditor, if corporate assets are insufficient to meet the liability, the counterparty will be left to bear the loss.

Let us take the accident victim as an example. Assume that a company has assets worth HK\$1 million (roughly $£ 80,000$ ). Its vehicle is involved in an accident in which an individual is injured. The driver of the company vehicle was clearly at fault and the company will be adjudged fully liable to the individual for his injuries should the case go to trial, even though the company has made its best effort to supervise its drivers. The individual's medical expenses amount to

79 See Davies, above n. 21 at 198-9; L. Sealy and S. Worthington, Cases and Materials in Company Law, 8th edn (Oxford University Press: Oxford, 2008) 61.

80 The term creditor is used in the general law and economics sense as opposed to the technical sense. 
HK\$1.2 million (roughly $£ 100,000$ ). Further assume that the victim is uninsured and would have to cover these expenses out-of-pocket if he was not compensated by the company. As mentioned earlier, the company only has assets worth HKS1 million. Therefore, even if the individual prevails in the lawsuit, the maximum recovery will be only HK\$1 million. He will have to bear the remaining loss of HK\$200,000 unless the corporate veil is lifted to impose personal liability on the company's members. Absent circumstances that justify veil lifting, the members will not be liable for the judgment against the company. The company's business costs, which include the accident costs arising from its business activities, have been externalized to the tort victim as a result of limited liability. One can easily imagine other situations in which a company's operations necessarily entail tort costs. Examples include a company that operates an explosives factory or a chemicals factory that emits hazardous pollutants into the air. If corporate assets fell short of liabilities, the tort costs of the business operations would be externalized. As has been argued persuasively by a number of commentators, there are no reasons why innocent third parties and society in general should subsidize business activities, especially hazardous or polluting ones. ${ }^{81}$

It has been argued that the justification for imposing shareholder liability is the strongest on behalf of tort victims, who generally do not have a prior opportunity to negotiate with the company for protection. $^{82}$ The justification for veil lifting is supposedly much weaker when it comes to contractual creditors who have had a prior opportunity to negotiate with the company. ${ }^{83}$ Assuming that a contractual creditor has had the opportunity to demand extra protection and is adequately compensated for the default risks it bears (perhaps in the form of a higher interest rate), there is no externalization of business risks. It was mentioned earlier that there are three types of contractual creditor: financial creditors, trade creditors, and employees. The veracity of these arguments depends on the extent to which these contractual creditors do in fact receive compensation for potential uncompensated losses.

There is little doubt that financial creditors are best positioned to negotiate with the company for additional credit protection such as shareholder personal guarantees. This is especially true for sophisticated financial creditors such as bank lenders. Loan transactions are usually worth a significant enough amount that the lender wields considerable bargaining power vis-à-vis the company. Bank lenders are also well equipped to assess a company's default risks. These

81 See Halpern, Trebilcock and Turnbull, above n. 35 at 145-7; H. Hansmann and R. Kraakman, 'Toward Unlimited Shareholder Liability for Corporate Torts' (1990) 100 Yale Law Journal 1879 at 1888.

82 See Halpern, Trebilcock and Turnbull, above n. 35 at 145-7; Hamilton, above n. 9 at 988.

83 See Easterbrook and Fischel, above n. 35 at 104-9. 
lenders are repeat players in the loan market and have accumulated a great deal of experience and expertise. For these creditors, veil lifting does not seem justified because they can demand extra credit protection in advance. If they fail to do so through carelessness of their own, they should be made to bear the consequence. Worse still, if they have received higher interest as compensation, and the default event materializes, they should not be allowed to renegotiate the original loan agreement ex post through veil lifting. Allowing them to recover from the members in such an event would amount to a windfall.

This line of reasoning does not apply to employees. For want of bargaining power, very few employees are in a position to demand extra compensation for the company's default risks. Given the fungibility of most employees, a company can easily move on to the next candidate if the first one asks for such compensation. In fact, most employees will not even have adequate information or the skill to assess their employers' default risks. The only exceptions may be senior executives and managerial staff. Therefore, in general, limited liability shifts a company's default risks onto its employees. When corporate assets are insufficient to cover a company's wage liabilities, it cannot be a defence against the imposition of shareholder liability that the employees had the opportunity to demand extra compensation and neglected to do so. With employees, the case for overriding limited liability is much stronger.

Trade creditors present the most diverse set of circumstances. Some trade creditors transact business of sufficient volume and value with the company that they may be in a good position to demand extra credit protection or compensation for default risks. For other trade creditors, the time costs of this negotiation outweigh the expected loss. One commonality among all trade creditors is that their credit is usually of a short enough duration that the perceived default risks are very low. This lowers their expected loss and causes many of them to forego extra credit protection. On balance, in terms of their ability and incentives to negotiate for extra protection, trade creditors are more similar to employees than financial creditors. This means that limited liability shifts corporate business costs onto trade creditors. When commentators assert that externalization of business costs does not apply to contractual creditors, they are focusing merely on financial creditors. Externalization does affect trade creditors and employees.

The most obvious response to this externalization argument is that counterparties are free to seek insurance coverage for their risk exposure to companies. A potential tort victim can purchase general accident insurance or health insurance. A financial creditor can purchase default protection, perhaps in the form of complex financial instruments such as credit default swaps. A trade creditor and an employee may be able to do the same. With adequate insurance coverage, there will be no externalization of business costs by the 
company. This argument, however, is flawed because the purchase of insurance is costly. The counterparty must pay a premium for the insurance coverage. Provided that the insurance coverage is accurately priced, the purchase of insurance does not eliminate the externalization of business costs. The only difference with an accurately priced insurance coverage is that the counterparty, instead of bearing the full loss in the event of an accident or default, bears its expected loss adjusted for the probability of the accident or default. Business costs are still borne by the counterparty in the form of insurance premiums.

\section{ii. The Corporate Veil Doctrine from a Development Perspective}

Having established that limited liability does result in externalization of business costs, the important question becomes whether the Hong Kong society should accept it as an inevitable consequence of limited liability. In order to answer this question, one needs to recognize the benefits as well as the costs of limited liability. The discussion thus far has focused on the costs of limited liability. This is an incomplete picture, however, as limited liability serves important economic functions. It helps to attract passive investments in corporate business ventures. Under unlimited shareholder liability, passive investors would be deterred from equity investments. ${ }^{84}$ Their inability to control and lack of incentives to monitor corporate business decisions means that passive investors could be potentially exposed to astronomical liability under an unlimited liability regime.

This effect is more relevant for public companies; private companies are less likely to attract substantial passive investments. This does not mean that limited liability is of little value to private companies. It performs important functions for them as well. Without limited liability, entrepreneurs will hesitate to launch new business ventures for fear of losing their entire personal fortunes. And if they do launch such ventures, they may go through considerable trouble and incur substantial expenses to put their personal assets beyond the reach of their companies' creditors. This can be accomplished through trusts and other complex financial structures. These expenses are socially wasteful and could be avoided under limited liability. This dampening effect on entrepreneurship, however, may be more apparent than real. In Hong Kong, owners of private companies are often required by their financial creditors to provide personal guarantees. Many of them in reality do not enjoy limited liability protection. Whether the Hong Kong society should make any adjustments to limited liability boils down to a weighing of the costs and benefits of the principle as delineated above. Adjustments to the principle can be made through the corporate veil doctrine. 
One of the central arguments of this section is that the weighing of these costs and benefits needs to take into account the state of economic development of the jurisdiction at issue. A developing country jurisdiction may justifiably take the view that entrepreneurship and business investments should be encouraged to the extent possible, including the use of limited liability to provide implicit subsidies to companies. The need to provide such subsidies is much weaker for a developed economy jurisdiction. To place this discussion in the context of limited liability, strict adherence to limited liability may be justified when an economy is undergoing rapid development. A more flexible approach is called for in an advanced economy so that the costs of limited liability can be kept in check.

The idea that development of legal doctrines should reflect the state of economic development of the jurisdiction is not as novel as it sounds. In fact, the history of US tort law and corporation law is replete with examples of this. US tort and corporation law doctrines were modified in the nineteenth century, when the US economy was undergoing rapid industrialization, to facilitate economic development. One such modification was the shift from strict liability to negligence as the common standard for tort liability from the midnineteenth century onwards. ${ }^{85}$ This shift made it more difficult for individuals to hold a corporation liable for injuries sustained from the defendant's business activities. Around the same time, the US courts also began to tinker with the doctrine of causation in torts to limit the liability of big businesses, most notably railroads, for the injuries caused by their activities. ${ }^{86}$ In fact, the introduction of limited liability among the various states in the US in the early nineteenth century was largely an effort to promote industrial growth. ${ }^{87}$ Many American courts subsequently adopted decisions that tended to uphold the separate personality of corporations. ${ }^{88}$ The incidental, or perhaps even intended, effect of these decisions was to encourage industrialization. ${ }^{89}$

In the case of Hong Kong, implicit subsidies to corporate ventures were perhaps justified during the rapid economic development period

85 M. Horwitz, The Transformation of American Law 1780-1860, 1st edn (Oxford University Press: Oxford, 1977) 99-101. However, this thesis has been subsequently challenged. See G. Schwartz, "Tort Law and the Economy in Nineteenth Century America: A Reinterpretation' (1981) 90 Yale Law Journal 1717.

86 M. Horwitz, The Transformation of American Law 1870-1960, 1st edn (Oxford University Press: Oxford, 1992) 57.

87 See Landers, above n. 52; E. Dodd, 'The Evolution of Limited Liability in American Industry: Massachusetts' (1948) 61 Harvard Law Review 1351; D. Leebron, 'Limited Liability, Tort Victims, and Creditors' (1991) 91 Columbia Law Review 1565.

However, some scholars have argued that the introduction of limited liability did not result in a proliferation of corporations, as was predicted. See K. Forbes, 'Limited Liability and the Development of Business Corporation' (1986) 2 Journal of Law, Economics, \& Organization 163; P. Blumberg, 'Limited Liability and Corporate Groups' (1986) 11 Journal of Corporation Law 573.

88 See Hamilton, above n. 9 at 980.

89 Ibid. 
from the 1950 s to 1980 s, when the city was poor and many local businesses were struggling to establish themselves. Similar to the US in the nineteenth century, Hong Kong underwent rapid industrialization between the 1950s and 1980s. Prior to the Korean War, Hong Kong was largely a trade entrepot between China and the rest of the world. ${ }^{90}$ However, the embargo imposed by the United Nations during the Korean War ended that trade and forced Hong Kong to look for economic alternatives. ${ }^{91}$ After the Communist takeover, many Shanghainese businessmen fled to Hong Kong with capital and knowhow in industries such as textiles, garments, toys, and inexpensive electronics. ${ }^{92}$ Despite this rapid industrialization, the GDP per capita of Hong Kong was still relatively low at the time. It was only US $\$ 4,744$ at the end of the 1960s in 2005 dollars, roughly one-quarter that of the United Kingdom. ${ }^{93}$ Although limited liability had been introduced to Hong Kong long before its industrialization began, businesses needed whatever advantages they could obtain during this period of rapid economic growth. The imperative of industrialization and economic growth means that the benefits of limited liability were significant and outweighed its costs, which in turn means that limited liability should be vigorously defended.

As the economy continued to grow, the city became wealthier. With the Open Door Policy of China starting in 1979, many Hong Kong businessmen moved their factories to China to take advantage of the almost inexhaustible supply of cheap labour across the border. ${ }^{94}$ The city began to transition to a service-based economy. By 1996, the city's GDP per capita had risen to about US $\$ 25,300$, only slightly below that of the US. ${ }^{95}$ By 2007, GDP per capita had reached US\$30,900. ${ }^{96}$ According to the US Central Intelligence Agency, The World Factbook, Hong Kong was ranked No. 15 in the world in terms of GDP per capita measured in purchasing power parity, 17 places higher than the UK. ${ }^{97}$ It is clear that by the 1990 s, the economy was sufficiently advanced that there was no longer any pressing need to promote industrialization and subsidize business activities. The benefits of limited liability have now waned, and the weighing of the costs and

90 T. Hagelin, 'Reflections on the Economic Future of Hong Kong' (1997) 30 Vanderbilt Journal of International Law 701 at 706; HKSAR Government, 2008 Hong Kong Yearbook, 1st edn (HKSAR Information Services Department: Hong Kong, 2008) 420.

91 See 2008 Hong Kong Yearbook, above n. 86 at 420.

92 Ibid.

93 The GDP per capita of the United Kingdom in 1969 was US $\$ 17,403$. US Department of Agriculture, Real Historical Gross Domestic Product (GDP) Per Capita and Growth Rates of GDP Per Capita for Baseline Countries/Regions (in 2005 dollars) 1969-2009, available at: www.ers.usda.gov/Data/.../Data/HistoricalRealPerCapita IncomeValues.xls (data source: ERS International Macroeconomic Dataset).

94 See Hagelin, above n. 86 at 707.

95 Ibid.

96 See Hong Kong Yearbook, above n. 86 at 41.

97 US Central Intelligence Agency, The World Factbook, available at: https://www.cia. gov/library/publications/the-world-factbook/rankorder/2004rank.html. 
benefits needs to be recalibrated to reflect the evolving socioeconomic environment of the city.

The important question is how to achieve this recalibration under Hong Kong law. If the principle of limited liability were not so deeply entrenched in the legal system of, and the business culture in, Hong Kong, and almost every other advanced economy for that matter, there may be room for revisiting it, as has been argued by some North American scholars. ${ }^{98}$ However, it is too late in the development of Hong Kong company law to question the validity of the principle. The best alternative is to expand the application of the corporate veil doctrine beyond cases involving fraud and criminal convictions. Through more judicious use of the doctrine, the occasionally harsh effects of limited liability can be alleviated. The high claimant success rate in corporate veil cases indicated in Section II may suggest that the Hong Kong courts have already been doing that. However, in many of these cases, externalization of business costs was not implicated. In only a few cases was the corporate veil doctrine used to tackle the problem. Lee Sow Keng and Yue Tai Plywood \& Timber were two notable examples. In the remaining cases, the veil was lifted for a variety of reasons that do not concern limited shareholder liability. For example, in Endenne Development, the veil was lifted in order to hold the defendants liable for misrepresentation, which the defendants were able to accomplish with the help of their corporate vehicle. This is different from the typical scenario of externalization of business costs, where a bona fide company shifts its business costs onto outside parties by virtue of its insufficient assets. Therefore, the adequate recalibration will entail a reformulation of the corporate veil doctrine in Hong Kong.

It cannot be the case that the doctrine applies anytime there is externalization of business costs, which would be tantamount to a repeal of limited liability. Some limiting principles on the doctrine are necessary. While a full discussion of the reformulation of the doctrine is beyond the scope of this paper, a few initial ideas can be offered. One possibility is an expansion of the evasion of existing legal obligations rule to encompass obligations that were reasonably foreseeable at the time of incorporation. This means that if a company chooses to enter a line of hazardous business activity, the court may find that accidents arising from the activity are reasonably foreseeable. An evasion of reasonably foreseeable legal obligations rule would allow a court to lift the veil. Another possibility is for the courts to pay greater attention to whether a company is adequately capitalized for its proposed business. Evidence of grossly inadequate capitalization may justify veil lifting. The courts may need to formulate certain objective standards for adequacy of capitalization and take into consideration

98 See Halpern, Trebilcock and Turnbull, above n. 35 at 145-7; Hansmann and Kraakman, above n. 77 at $1879-82$. 
subjective facts of the case, such as the incorporators' intent. In fact, adequacy of capitalization and reasonable foreseeability of legal obligations can be combined as one single test for veil lifting cases where fraud is absent.

A reformulated corporate veil doctrine will not address externalization of corporate business costs in all instances. However, this cannot be achieved absent a dramatic curtailment of limited liability. Having decided that the limited liability principle is too entrenched to be revisited at this point, compromises that do not address every instance of externalization of corporate business costs must be accepted.

\section{Conclusion}

The goal of this paper is to provide some clarity on the corporate veil doctrine in Hong Kong. With a comprehensive survey, the case law was analysed along the following dimensions: the nature of the underlying claims at issue, the nature of the company, the number and identity of the shareholders in the company, the reasons given by the courts, and the time at which the case was decided. Results of the survey suggest that some of the common perceptions about the doctrine are inaccurate. For example, a general belief is that the Hong Kong courts are averse to the corporate veil doctrine. The survey debunked this belief and showed that the Hong Kong courts have applied the doctrine quite actively. They have lifted the veil in more than 50 per cent of the cases in which the doctrine was invoked. The survey confirmed that the US and Hong Kong cases share the same trend in success rate across case types. The Hong Kong courts are the most ready to lift the veil in criminal cases, then statutory cases, and lastly contract cases. Surprisingly, no corporate veil claim has ever been raised in a tort case in Hong Kong.

Unsurprisingly, the Hong Kong courts have never lifted the veil against a public company. However, in contrast to their American counterparts, the Hong Kong courts are more likely to lift the veil as the number of shareholders in the company increases. This is a somewhat counter-intuitive result. Among the bases commonly invoked by the Hong Kong courts to lift the veil, fraud and evasion of existing legal obligations are the only two that have featured frequently enough among the cases to be of any predictive significance. Lastly, it was discovered that judicial attitude towards the doctrine has ebbed over time. Claimant success rate rose substantially from the 1980 s to the 1990s, and has held steady since. No obvious explanation presents itself for this trend. One possibility is that the Hong Kong courts only became comfortable enough with the doctrine in the 1990s to apply it on a regular basis. 
This paper also suggests a possible future direction for the corporate veil doctrine by putting it in a development perspective. The argument is premised on the realization that limited liability results in the externalization of business costs onto contractual and tortious creditors of a company. This externalization is tantamount to an implicit subsidy for corporate business activities. At the same time, limited liability serves some very important purposes by encouraging entrepreneurship and corporate business investments. The extent to which the limited liability principle should be adhered to depends on a weighing of the costs and benefits of the principle. One further premise of the argument is that the benefits of limited liability diminish as a society becomes more developed economically. What this means is that there are fewer persuasive justifications for a strict adherence to limited liability in an advanced economy like Hong Kong's. Under appropriate circumstances, the corporate veil doctrine should be used to rectify the externalization of corporate business costs. This would allow limited liability to continue to serve its useful functions without producing unduly harsh effects on the counterparties of companies. 